\title{
PENGARUH PENDIDIKAN KESEHATAN ANIMASI LAGU ANAK- ANAK TERHADAPPENGETAHUAN CUCI TANGAN PAKAI SABUN (CTPS) ANAK USIA SEKOLAH PADAMASA PANDEMI COVID-19 DI DESA GEMBOL NGAWI
}

\author{
The Effect Of Health Education Animated Children's Song On School-Age During The Pandemic \\ Covid-19In Gembol Ngawi Village
}

\author{
Krisnanda Aditya Pradana ${ }^{1}$, Yuly Peristiowati ${ }^{2}$, \\ Agusta Dian Ellina ${ }^{3}$, Aris Widiyanto ${ }^{4}$, Joko Tri Atmojo ${ }^{5}$ \\ 1),2),3) IIK STRADA Indonesia, Jl. Manila No.37, Tosaren, Pesantren, Kota Kediri, \\ Jawa Timur, Indonesia 64113 \\ 4), 5) STIKES Mamba’ul Ulum Surakarta, Jl. Ring Road Utara, Tawangsari, \\ Mojosongo, Jebres, Kota Surakarta, Jawa Tengah, Indonesia 57127
}

Krisnanda.pradana@gmail.com

\begin{abstract}
ABSTRAK
Latar Belakang: Pendidikan kesehatan cuci tangan pakai sabun (CTPS) sangat penting untuk diketahui sejak dini agar dapat terhindar dari berbagai permasalahan penyakit pada anak-anak terutama sejak terjadi pandemi covid 19 . Cuci tangan pakai sabun (CTPS) menjadi salah satu pencegahan yang di promosikan oleh pemerintah. Upaya untuk meningkatkan pengetahuan cuci tangan pakai sabun (CTPS) dapat dilakukan dengan pendidikan kesehatan menggunakan media dan alat yang menarik.
\end{abstract}

Tujuan penelitian: Mengetahui pengaruh pendidikan kesehatan animasi lagu anak-anak terhadap pengetahuan cuci tangan pakai sabun (CTPS) anak usia sekolah pada masa pandemi Covid-19 di Desa Gembol Ngawi.

Metode: Desain penelitian adalah penelitian quasi eksperimental dengan rancangan penelitian pre and post test without control. Subjek penelitian adalah 30 anak usia sekolah. Alat pengumpulan data menggunakan kuesioner. Analisis data dengan analisis univariat menggunakan rumus distribusi frekuensi dan analisa bivariat uji wilcoxon.

Hasil: Pengetahuan responden sebelum pendidikan kesehatan animasi lagu anakanak mayoritas pengetahuan yang cukup 56,7\% dan setelah pendidikan kesehatan animasi lagu anak-anak mayoritas menjadi pengetahuan yang baik $73,3 \%$. Uji wilcoxon didapatkan uji wilcoxon $\mathrm{P}$ value 0,000 sehingga terdapat pengaruh animasi lagu terhadap pengetahuan cuci tangan pakai sabun (CTPS) anak usia sekolah pada masa pandemi covid-19.

Simpulan: Pendidikan kesehatan animasi lagu anak-anak dapat meningkatkan pengetahuan cuci tangan pakai sabun (CTPS) anak usia sekolah pada masa pandemi Covid-19 di Desa Gembol Ngawi.

Kata Kunci: Pengetahuan, Pendidikan Kesehatan, Cuci Tangan Pakai Sabun (CTPS) 
Krisnanda Aditya Pradana dkk (Pengaruh Pendidikan Kesehatan Animasi Lagu Anak-Anak Terhadap Pengetahuan Cuci Tangan Pakai Sabun (CTPS) Anak Usia Sekolah PadaMasaPandemiCovid-19 DiDesa Gembol Ngawi)

\begin{abstract}
Background: Washing hands with soap (CTPS) health education is very important to know from an early age in order to avoid various disease problems in children, especially since the Covid 19 pandemic. Washing hands with soap (CTPS) is one of the prevention promoted by the government. Efforts to increase knowledge of washing hands with soap (CTPS) can be done with health education using interesting media and tools..

Research purposes: Knowing the effect of children's song animation health education on the knowledge of washing hands with soap (CTPS) of school-age children during the Covid-19 pandemic in Gembol Ngawi Village.

Methods: The research design was a quasi experimental research design with pre and post test without control. The research subjects were 30 school age children. The data collection tool used a questionnaire. Data analysis with univariate analysis using frequency distribution formulas and bivariate analysis of Wilcoxon test.

Results: The majority of respondents' knowledge before health education about children's song animation was 56.7\% sufficient and after health education, the majority of children's song animation became good knowledge, 73.3\%. The Wilcoxon test showed that the Wilcoxon P value was 0,000 so that there was an effect of song animation on the knowledge of washing hands with soap (CTPS) of school-age children during the Covid-19 pandemic.

Conclusion: Animated children's song health education can increase knowledge of washing hands with soap (CTPS) for school-age children during the Covid-19 pandemic in Gembol Ngawi Village.
\end{abstract}

Keywords: Knowledge, Health Education, Washing Hands With Soap (CTPS)

\title{
PENDAHULUAN
}

Pandemi Covid-19 merupakan musibah yang memilukan seluruh penduduk disemua Negara (Kemenkes, 2020). Virus Corona adalah virus yang menyerang sistem pernapasan bisa menyebabkan gangguan ringan pada sistem pernapasan, infeksi paru-paru yang berat, hingga kematian (Fadli, 2020). Tanda dan gejala umum infeksi COVID-19 antara lain gejala gangguan pernapasan akut seperti demam, batuk dan sesak napas. Masa inkubasi rata-rata 5-6 hari dengan masa inkubasi terpanjang 14 hari. Pada kasus COVID-19 yang berat dapat menyebabkan pneumonia, sindrom pernapasan akut, gagal ginjal, dan bahkan kematian (Kemenkes, 2020). Penularan dapat melalui droplet yang keluar saat batuk atau bersin dan masuk pada hidung, mata dan mulut (Susilo dkk, 2020).

Terjadinya bencana Virus Corona (COVID 19) memberikan pengaruh terhadap keresahan terhadap masyarakat terutama anak-anak (Ibrahim dkk, 2020). Anak dalam masa pertumbuhan yang memiliki respon imun dan kekuatan pertahanan dirinya yang belum optimal hingga anak rentan terhadap berbagai 
Krisnanda Aditya Pradana dkk (Pengaruh Pendidikan Kesehatan Animasi Lagu Anak-Anak TerhadapPengetahuan Cuci Tangan Pakai Sabun (CTPS) Anak Usia Sekolah PadaMasaPandemiCovid-19 DiDesaGembolNgawi)

penyakit (Rini, 2013). Anak-anak dan remaja memiliki risiko besar untuk mengalami komplikasi dan kondisi yang parah jika terpapar Covid-19. Anak-anak rentan mengalami keparahan terutama memiliki kondisi kronis bawaan termasuk obesitas (Dewi, 2020). Selain itu menurut Widiyanto (2020) mengatakan Covid 19 sebagai pandemi, ini berdampak pada kesehatan mental pada anak-anak disebabkan karena orang-orang harus tetap berada di rumah dan tidak diketahui kapan aturan jaga jarak sosial berakhir.

Pencegahan Covid-19 yang diterapakan oleh pemerintah berupa jaga jarak dalam berkomunikasi sosial, menjaga kesehatan, menghindari kerumunan, menghindari tempat berkumpul dan memutus rantai penularan dengan rajin cuci tangan dengan sabun (Astuti, 2020). Cuci tangan menggunakan sabun merupakan salah satu upaya pencegahan dan penularan penyakit. Cuci tangan pakai sabun dapat membunuh kuman sebanyak $73 \%$ dan lebih efektif membunuh kuman penyakit dibandingkan menggunakan hand sanitizer yang hanya membunuh kuman sebanyak 60\% (Cordita dkk, 2019).

Mencuci tangan dengan sabun dipengaruhi oleh beberapa faktor, diantaranya pengetahuan akan pentingnya mencuci tangan dengan sabun, keterampilan akan cara mencuci tangan yang benar, ketersediaan sarana untuk mencuci tangan, dan juga pengaruh dukungan sosial dari lingkungan sekitar (Tambunan, 2011). CPTS dapat menurunkan 50\% insiden avian influenza (Talaat, 2016).

Hasil penelitian Trijayanti (2019) pengetahuan kurang mengenai cuci tangan pakai sabun sebanyak 47,1\%. Menurut Kartika dkk (2016) mengatakan kurangnya pengetahuan anak sekolah dasar dalam melakukan cuci tangan pakai sabun disebabkan oleh faktor penyampaian informasi melalui pelajaran ataupun media promosi kesehatan yang kurang menarik dan mudah dipahami siswa. Masa pandemi Covid-19 Kemenkes melakukan beberapa upaya untuk meningkatkan pengetahuan masyarakat dengan penyampaian press release terkait Covid-19, temu media dan talkshow, sebagai upaya komunikasi risiko kepada masyarakat serta pembuatan materi edukasi bagi masyarakat untuk disebarluaskan melalui berbagai mediasalah satunya novel coronavirus (PAPDI, 2020).

Pendidikan kesehatan sangat penting untuk menambah pengetahuan dan salah satu proses promosi kesehatan yang paling sederhana bagi setiap manusia dalam menjaga kesehatan tubuh (Notoadmojo, 2012). Sarana untuk menyampaikan pendidikan kesehatan diperlukan sebuah media. Media promosi kesehatan digunakan untuk menampilkan pesan atau informasi kesehatan yang ingin disampaikan kepada seseorang sehingga dapat meningkatkan pengetahuan dan dapat mengubah ke arah perilaku yang positif. Ada beberapa media yang digunakan dalam promosi kesehatan diantaranya yaitu cetak, elektronik, dan luar ruangan (Mutiarani, 2018).

Salah satu media dan alat yang bisa digunakan untuk melengkapi pendidikan kesehatan yaitu terapi musik. Terapi musik sangat baik dalam mempengaruhi perasaan atau emosional seseorang sehingga menciptakan suasana yang lebih nyaman dan memberikan rasa bahagia (Lina \& Rita, 2016). Terapi musik bisa didapatkan dari lagu anak-anak, lagu anak - anak dikenal sebagai lagu yang mempunyai irama (ketukan tidak teratur), nada, lirik yang mudah dipahami dan birama (ketukan teratur) yang sederhana dalam arti mudah dihafalkan dan 
diekspresikan dan sesuai dengan tingkat usia untuk anak usia 3-6 tahun. Lagu anak -anak cocok untuk dijadikan stimulasi perkembangan terhadap anak usia 3-6 tahun (Rasyid, 2012).

Penambahan karakter animasi pada video klip lagu anak-anak dengan teknik animasi 3D bisa menarik perhatian anak-anak dengan memunculkan karakter yang lucu dan menghibur anak-anak (Wijaya et al, 2015). Hasil penelitian Putri (2016) didapatkan media lagu lebih efektif daripada slide terhadap praktik mencuci tangan pada siswa TK Negeri Pembina Sragen.

\section{METODE}

Penelitian ini merupakan penelitian kuantitatif, dengan pendekatan quasi eksperimental dengan rancangan penelitian pre and post test without control (kontrol diri sendiri). Penelitian ini dilakukan di Desa Gembol, Kecamatan Karanganyar, Kabupaten Ngawi. Penelitian ini dilakukan pada bulan Desember 2020 - Januari 2021. Peneliti menggunakan 30 responden dengan teknik pengumpulan data yang digunakan pada penelitian ini ialah purposive sampling.

\section{HASIL DAN PEMBAHASAN}

\section{Hasil}

1. Karakteristik responden berdasarkan umur.

Tabel 1 Distribusi frekuensi karakteristik responden berdasarkan umur

\begin{tabular}{cccccc}
\hline Karakteristik & \multicolumn{5}{c}{ Penilaian } \\
\cline { 2 - 6 } & Min & Max & Mean & SD & Median \\
\hline Usia & 9 & 12 & 10,7 & 0,67 & 10 \\
\hline Sumber: Data primer 2021 & & & &
\end{tabular}

Berdasarkan tabel 1 di atas menunjukkan bahwa rata-rata umur adalah 10 tahun dengan median 10, standar deviasi 0,67, usia termuda 9 tahun dan usia tertua 12 tahun.

2. Karakteristik responden berdasarkan jenis kelamin

Tabel 2 Distribusi frekuensi karakteristik responden berdasarkan jenis kelamin

\begin{tabular}{lcc}
\hline Jenis Kelamin & F & \% \\
\hline Laki-Laki & 10 & 33,4 \\
Perempuan & 20 & 66,6 \\
Total & 30 & 100 \\
\hline
\end{tabular}

Sumber: Data primer 2021

Berdasarkan tabel 2 di atas dapat disimpulkan sebagian besar responden adalah berjenis kelamin perempuan sebanyak 20 responden $(66,6 \%)$. 
Krisnanda Aditya Pradana dkk (Pengaruh Pendidikan Kesehatan Animasi Lagu Anak-Anak Terhadap Pengetahuan Cuci Tangan Pakai Sabun (CTPS) Anak Usia Sekolah PadaMasaPandemiCovid-19 DiDesa Gembol Ngawi)

3. Pengetahuan Cuci Tangan Pakai Sabun (CTPS) Anak Usia Sekolah Sebelum Pemberian Animasi Lagu

Tabel 3 Distribusi frekuensi pengetahuan cuci tangan pakai sabun (CTPS) anak usia sekolah sebelum pemberian animasi lagu

\begin{tabular}{lcc}
\hline Pengetahuan & F & \% \\
\hline Baik & 5 & 16,7 \\
Cukup & 17 & 56,7 \\
Kurang & 8 & 26,6 \\
Total & 30 & 100 \\
\hline
\end{tabular}

Sumber: Data primer 2020

Berdasarkan tabel 3 di atas dapat disimpulkan sebagian besar responden memiliki pengetahuan yang cukup sebanyak 17 responden $(56,7 \%)$.

4. Pengetahuan Cuci Tangan Pakai Sabun (CTPS) Anak Usia Sekolah Sesudah Pemberian Animasi Lagu.

Tabel 4 Distribusi frekuensi pengetahuan cuci tangan pakai sabun (CTPS) anak usia sekolah sesudah pemberian animasi lagu

\begin{tabular}{lcc}
\hline Pengetahuan & F & \% \\
\hline Baik & 22 & 73,3 \\
Cukup & 6 & 20 \\
Kurang & 2 & 6,7 \\
Total & 30 & 100 \\
\hline
\end{tabular}

Sumber: Data primer 2021

Berdasarkan tabel 4 di atas dapat disimpulkan sebagian besar responden memiliki pengetahuan yang baik sebanyak 22 responden $(73,3 \%)$.

5. Pengaruh Animasi Lagu Terhadap Pengetahuan Cuci Tangan Pakai Sabun (CTPS) Anak Usia Sekolah

Tabel 5 Hasil uji wilcoxon

\begin{tabular}{lcc}
\hline \multicolumn{1}{c}{ Karakteristik } & Z & P value \\
\hline Pengaruh Animasi Lagu Terhadap & $-4,105$ & 0,000 \\
Pengetahuan Cuci Tangan Pakai Sabun & & \\
(CTPS) Anak Usia Sekolah & & \\
\hline \multicolumn{2}{l}{ Sumber: Data primer 2021 }
\end{tabular}

Berdasarkan tabel 5 di atas dapat disimpulkan hasil analisa uji wilcoxon nilai $P$ value $=0,000$ sehingga $P$ value $<0,05$ maka $\mathrm{H} 0$ di tolak dan Ha di terima sehingga dapat disimpulkan terdapat pengaruh animasi lagu terhadap pengetahuan cuci tangan pakai sabun (CTPS) anak usia sekolah pada masa pandemi covid-19 di Desa Gembol Ngawi 
Krisnanda Aditya Pradana dkk (Pengaruh Pendidikan Kesehatan Animasi Lagu Anak-Anak TerhadapPengetahuan Cuci Tangan Pakai Sabun (CTPS) Anak Usia Sekolah PadaMasaPandemiCovid-19 DiDesaGembolNgawi)

\section{Pembahasan}

Berdasarkan hasil tabel 1 hasil penelitian ini didapatkan usia pada anak sekolah menunjukkan bahwa rata-rata usia adalah 10 tahun. Sejalan dengan hasil penelitian Lambu dkk (2018) mengatakan usia anak sekolah mayoritas 10 tahun sebanyak 16 responden (20,5\%). Umur anak 6 sampai 12 tahun atau anak yang masih duduk disekolah dasar masih rentang terkena penyakit (Neng \& Septian, 2015). Usia sekolah dasar (SD/MI) adalah sasaran utama dalam implementasi hidup sehat. Pembiasaan berpola hidup sehat harus terus digalakkan pada anak usia dini dengan cara cuci tangan dengan sabun, memotong kuku atau menjaga lingkungan sekitar (Suprapto dkk, 2020).

Berdasarkan hasil tabel 2 hasil penelitian ini didapatkan jenis kelamin pada anak sekolah mayoritas perempuan sebanyak 20 responden $(66,6 \%)$. Sejalan dengan hasil penelitian Kusumawardhani dkk (2017) mengatakan mayoriras jenis kelamin pada anak usia sekolah adalah perempuan sebanyak 18 responden $(62 \%)$. Jenis kelamin perempuan lebih memahami pentingnya cuci tangan dibandingkan dengan responden dengan jenis kelamin laki-laki. Hal tersebut dapat terlihat dalam bentuk praktik cuci tangan yang benar lebih banyak dilakukan responden perempuan dibandingkan dengan responden laki-laki. Hal ini disebabkan anak perempuan mengalami lonjakan pertumbuhan pada masa usia sekolah. Anak perempuan lebih tinggi, lebih kuat, dan lebih terampil dalam aktivitas otot kecil sehingga anak perempuan akan lebih memperhatikan kebersihan diri (Click, 2014).

Berdasarkan hasil tabel 3 didapatkan pengetahuan cuci tangan pakai sabun (CTPS) anak usia sekolah sebelum pemberian pendidikan kesehatan animasi lagu anakanak sebagian besar pengetahuan yang cukup sebanyak 17 responden $(56,7 \%)$. Responden dalam penelitian ini merupakan anak usia sekolah yang belum pernah mendapatkan pendidikan kesehatan dari sekolahan ataupun tenaga kesehatan akan tetapi pernah melihat di televisi cara mencuci tangan pakai sabun. Hal ini dapat mendukung tingkat pengetahuan responden mengenai cuci tangan pakai sabun (CTPS). Hasil penginderaan manusia, atau hasil tahu seseorang terhadap objek melalui indera yang dimilikinya. Pengetahuan merupakan salah satu bagian dari perilaku, sebagaimana yang dikemukakan oleh Notoatmodjo (2014), membagi perilaku seseorang ke dalam tiga domain yakni pengetahaun (cognitive domain), sikap (affevtive domain), dan tindakan (psychomotor domain). Kognitif dapat diukur dari pengetahuan, afektif dari sikap atau tanggapan dan psikomotor diukur melalui tindakan (praktik) yang dilakukan (Notoatmodjo, 2014). Pengetahuan atau kognitif merupakan domain yang sangat penting dalam membentuk sikap dan tindakan seseorang (Nasution, 2014). Selain itu pengetahuan juga bersifat benar karena sesuai dengan realitas yang ada (Suryana, 2015). Seseorang yang tidak memiliki pengetahuan tentang cuci tangan pakai sabun (CTPS), akan cenderung mengabaikan kesehatannya dan pada akhirnya ia akan melakukan tindakan yang membahayakan bagi dirinya sendiri.

Berdasarkan hasil tabel 4 didapatkan pengetahuan cuci tangan pakai sabun (CTPS) anak usia sekolah setelah pemberian pendidikan kesehatan animasi lagu anak-anak sebagian besar pengetahuan yang baik sebanyak 22 responden $(73,3 \%)$. Pemilihan media sebagai penunjang proses penyuluhan kesehatan juga sama 
Krisnanda Aditya Pradana dkk (Pengaruh Pendidikan Kesehatan Animasi Lagu Anak-Anak TerhadapPengetahuan Cuci Tangan Pakai Sabun (CTPS) Anak Usia Sekolah PadaMasaPandemiCovid-19 DiDesaGembolNgawi)

pentingnya karena dengan adanya media sebagai penyampai pesan yang tepat bagi sasaran, maka pesan yang akan disampaikan juga dapat diterima dengan baik oleh sasaran (Notoatmodjo, 2014). Sebagian besar pengetahuan manusia diperoleh melalui mata dan telinga seperti didapatkan dari media poster, buklet, leaflet, slide atau informasi yang berupa tulisan dan informasi yang berbentuk suara seperti ceramah, video yang membantu menstimulasi penginderaan dalam proses pembelajaran (Efendy, Ferry \& Makhfudli, 2012). Hal ini karena pendidikan kesehatan membantu responden untuk mengontrol kesehatan hal ini karena responden terpapar informasi tentang cuci tangan pakai sabun (CTPS) sehingga mempengaruhi pengetahuan.

Berdasarkan hasil tabel 4 didapatkan hasil analisa uji wilcoxon nilai $P$ value $=0,000$ sehingga terdapat pengaruh animasi lagu terhadap pengetahuan cuci tangan pakai sabun (CTPS) anak usia sekolah pada masa pandemi covid-19 di Desa Gembol Ngawi. Musik atau suara mampu memberi pengaruh secara emosional terhadap makhluk hidup, musik meningkatkan kerja otot, mengaktifkan motorik kasar dan halus, musik meningkatkan produktifitas, kreatifitas dan imajinasi, musik menyebabkan tubuh menghasilkan hormon beta-endorfin (Nela, 2018). Media film juga mampu melukiskan gambar hidup dan suara memberikan daya tarik tersendiri sehingga selain menjadi media hiburan juga dapat digunakan sebagai media edukasi yang mudah dipahami dari anak-anak hingga orang tua (Parasyanti dkk, 2020). Media ini sangat efektif dalam penyampaian pesan karena seseorang mampu mengingat $20 \%$ dari apa yang dilihat, $30 \%$ dari apa yang didengar dan orang dapat mengingat 50\% dari yang dilihat dan didengar, serta $80 \%$ dari yang dilihat, didengar dan dilakukan langsung (Suiraoka \& Supariasa, 2012).

Unsur grafis pada sajian anak-anak adalah unsur yang paling penting karena pada anak-anak unsur lisan dan audio hanya mendapatkan perhatian sebesar 2\% dan 98\% sisanya diporsikan pada unsur visual statis (Evans dkk., 2013). Anak-anak menyukai unsur-unsur seperti gambar, warna dan cerita pada kartun animasi. Unsur-unsur seperti gambar, warna, cerita, dan emosi (senang, sedih, seru, bersemangat) yang terdapat pada kartun merupakan unsur otak kanan dan suara yang timbul dari film tersebut merupakan unsur otak kiri. Sehingga dengan menonton kartun animasi otak kanan dan otak kiri anak pada saat yang bersamaan digunakan dua-duanya secara seimbang dan anak fokus pada film kartun (Windura, 2010). Musik mampu memberi pengaruh secara emosional terhadap makhluk hidup, musik meningkatkan kerja otot, mengaktifkan motorik kasar dan halus, musik meningkatkan produktifitas, kreatifitas dan imajinasi, musik menyebabkan tubuh menghasilkan hormon beta-endorfin. Ketika mendengar suara yang indah maka homon 'kebahagiaan' (beta-endorfin) akan berproduksi, musik membentuk sikap seseorang seperti meningkatkan suasana hati sehingga kecemasan menurun (Nela, 2018).

Hal ini dikarenakan pendidikan kesehatan animasi lagu anak-anak ditayangkan dan ditangkap dengan melibatkan berbagai alat indera seperti penglihatan dan pendengaran, waktu pelaksanaan juga tidak memakan waktu lama namun semua pesan yang disampaikan dapat diterima oleh anak usia sekolah. Menurut Widiyanto (2020) mengatakan adanya pemberian informasi kesehatan 
Krisnanda Aditya Pradana dkk (Pengaruh Pendidikan Kesehatan Animasi Lagu Anak-Anak TethadapPengetahuan Cuci Tangan Pakai Sabun (CTPS) Anak Usia Sekolah PadaMasa PandemiCovid-19 DiDesa Gembol Ngawi)

yang perlu diterapkan oleh masyarakat diharapkan dapat memotivasi masyarakat dan memberdayakan masyarakat untuk bisa memperhatikan kesehatannya sehingga masyarakat memiliki kualitas hidup yang optimal.

\section{SIMPULAN DAN SARAN}

\section{Simpulan}

Berdasarkan hasil penelitian yang dilakukan dapat disimpulkan sebagai berikut karakteristik responden rata-rata berusia 10 tahun. Mayoritas jenis kelamin responden perempuan sebesar 66,6\%. Pengetahuan responden sebelum pendidikan kesehatan animasi lagu anak-anak mayoritas pengetahuan yang cukup $56,7 \%$ dan setelah pendidikan kesehatan animasi lagu anak-anak mayoritas menjadi pengetahuan yang baik $73,3 \%$. Hasil uji wilcoxon nilai $P$ value 0,000 sehingga terdapat pengaruh animasi lagu terhadap pengetahuan cuci tangan pakai sabun (CTPS) anak usia sekolah pada masa pandemi covid-19 di Desa Gembol Ngawi

\section{Saran}

Berdasarkan simpulan diatas dapat diajukan saran bahwa anak usia sekolah harus mendapatkan pendidikan kesehatan tentang cuci tangan pakai sabun (CTPS) mulai dari sekolahan, Desa dan tenaga kesehatan. Serta keluarga mendukung untuk mendampingi anak-anak dalam melakukan cuci tangan pakai sabun (CTPS). Kepada guru diharapkan memberikan dorongan kepada anak-anak agar selalu menjaga kebersihan tangan dengan memberikan fasilitas cuci tangan di sekolah. Institusi kesehatan dapat mengadakan sosialisasi kesehatan cuci tangan pakai sabun (CTPS) di sekolah-sekolah.

\section{DAFTAR PUSTAKA}

Astuti, N. A. R. (2020) "Pemerintah: 7 Provinsi- 41 Kabupaten/Kota Tetapkan Status Siaga Darurat Corona“, News.Detik.Com.

Cordita R, Soleha T, Mayasari D.(2019).Perbandingan Efektivitas Mencuci Tangan MenggunakanHand Sanitizerdengan Sabun Antiseptik pada Tenaga Kesehatan di Ruang ICU RSUD Dr. H. Abdul Moeloek.J Agromedicin.6(1)

Dewi H.(2020).Studi Terbaru, tingkat keparahan Covid-19 pada anak dan remaja lebih tinggi. https://kesehatan.kontan.co.id/. Diakses 13 januari 2021

Dewi W.(2020).Dampak COVID-19 terhadap Implementasi Pembelajaran Daring di Sekolah Dasar. Edukatif Jurnal Ilmu Pendidikan.2(1)

Efendi, Ferry. Makhfudli. (2012). Keperawatan Kesehatan Komunitas.Jakarta: Salemba Medika

Fadli A.(2020). Mengenal Covid-19 Dan Cegah Penyebarannya Dengan "Peduli Lindungi" Aplikasi Berbasis Andorid. https://www.researchgate.net/publication/340790225 
Krisnanda Aditya Pradana dkk (Pengaruh Pendidikan Kesehatan Animasi Lagu Anak-Anak TerhadapPengetahuan Cuci Tangan Pakai Sabun (CTPS) Anak Usia Sekolah PadaMasa PandemiCovid-19 DiDesaGembol Ngawi)

Ibrahim, Kamaluddin, Mas'ad, Mintasrihardi, Junaid, dkk.(2020). Bencana Virus Corona Melalui Sosialisasi Pada Anak Usia Dini Pada Desa Rempe Kecamatan Seteluk Sumbawa Barat. Jurnal Pengabdian Masyarakat Berkemajuan.3(2)

Kemenkes RI. (2020) . Perkembangan Covid-19. https://www.sehatnegeriku.kemenkes.go.id.

Kusumawati, Dwi R, Sulastri, Arifah S (2012). Hubungan Tingkat Pengetahuan Ibu Tentang Diare Dengan Penanganan Diare Pada Balita Selama Di Rumah Sebelum Dibawa Ke Rumah Sakit Islam Surakarta. Fakultas Ilmu Kesehatan Universitas Muhammadiyah Surakarta. Diakses pada tanggal 19 Oktober 2019.http://eprints.ums.ac.id/20548/

Lina P \& Rita D.H.(2016). Perbedaan Efektivitas Terapi Bermain Bercerita dan Musik terhadap Kecemasan Akibat Tindakan Injeksi pada Anak Usia Prasekolah (3-6 Th) di RSI Muhammadiyah Pekajangan Kabupaten Pekalongan. https://anzdoc.com/queue/lina-purnawati-rita-dwi-hartantiprogram-studi-ners-sekolah-.html

Neng F, Septian A.(2015).Hubungan Antara Pengetahuan Dengan Sikap Anak Usia Sekolah Akhir (10-12 Tahun) Tentang Makanan Jajanan Di Sd Negeri Ii Tagog Apu Padalarang Kabupaten Bandung Barat Tahun 2015.Jurnal Pendidikan Keperawatan Indonesia.5(1)

Notoatmodjo S. (2012). Promosi Kesehatan dan Perilaku Kesehatan. Jakarta: PT Rineka Cipta.

Notoatmodjo, S.(2014). Ilmu Perilaku Kesehatan. Jakarta: Rineka Cipta

PAPDI.(2020). Kesiapan Kemenkes Dalam Menghadapi Outbreak Novel Coronavirus (2019-nCoV).

https://www.papdi.or.id/pdfs/817/dr\%20Siti\%20Nadia\%20-

\%20Kemenkes\%20RI.pdf. 10 Januari 2021

Rasyid, D. (2012). Cerdaskan anakmu dengan musik. Yogyakarta: Diva Press.

Rini D.(2013).Hubungan Penerapan Atraumatic Care DenganKecemasan Anak Prasekolah Saat ProsesHospitalisasi Di RSU dr. H. KoesnadiKabupaten Bondowoso.https://repository.unej.ac.id/bitstream/handle/123456789/317 3/Debbi\%20Mustika\%20Rini\%20-\%20092310101065.PDF

Suryana, Y., (2015). Metode penelitian. Bandung, CV Pustaka Setia

Susilo A, Rumende M, Pitoyo C, Santoso W, Yulianti M, dkk.(2020). Coronavirus Disease 2019: Tinjauan Literatur Terkini. Jurnal Penyakit Dalam Indonesia.7(1)

Talaat, M. (2016). Effects of Hand Hygiene Campaigns on Incidence of Laboratory-confirmed Influenza and Absenteeism in Schoolchildren, Cairo, Egypt.Emerging Infectious Disease journal-CDC.17(4)

Tambunan.(2011).Cuci Tangan Pakai Sabun, Modul Kelompok Pendukung Ibu, USAID : Mercy Corps

Trijayanti D.(2019). Perilaku Tentang Cuci Tangan Pakai Sabun Di Madrasah Ibtidaiyah Taswirul Afkar.Jurnal Promkes.7(1):47-56.

Widiyanto A, Fajriah AS, Atmojo JT, Handayani RT, Kurniavie LE.(2020). The Effectof Social Media Exposure on Depression and Anxiety Disorders 
Avicenna : Journal of Health Research, Vol 4 No 1. Maret 2021 (24 - 33)

Krisnanda Aditya Pradana dkk (Pengaruh Pendidikan Kesehatan Animasi Lagu Anak-Anak Terhadap Pengetahuan Cuci Tangan Pakai Sabun (CTPS) Anak Usia Sekolah Pada Masa PandemiCovid-19 DiDesaGembol Ngawi)

inFacing Covid-19 Pandemic. European Journal of Molecular \& Clinical Medicine.7(5)

Widiyanto A, Atmojo JT, Fajriah AS, Putri SI, Akbar PS.(2020). Pendidikan Kesehatan Pencegahan Hipertensi. .1(2):96-190

Wijaya R.A, Maria N, dan Aniendya C.(2015). Perancangan Video Klip Lagu Anak "Indahnya Cinta" Dengan Teknik Animasi 3D.diakses 20 Januari 2021. https://media.neliti.com/media/publications/80182-ID-none.pdf

Windura. (2010). Pengaruh Teknik Distraksi Menonton Kartun Animasi terhadap Ansietas Anak Usia Sekolah selama Hospitalisasi. Jurnal Keperawatan Unand. 4 (1) : 21-32 